\title{
Cytotoxic, antitumor and leukocyte migration activities of resveratrol and sitosterol present in the hidroalcoholic extract of Cissus sicyoides L., Vitaceae, leaves
}

\author{
Flávia R. S. Lucena, ${ }^{* 1}{ }^{, 1}$ Edvaldo R. Almeida, ${ }^{2}$ Jaciana S. Aguiar, ${ }^{1}$ Teresinha G. Silva, ${ }^{3}$ \\ Valdênia M. O. Souza, ${ }^{4}$ Silene C. Nascimento ${ }^{1}$
}

\author{
${ }^{1}$ Laboratory of Culture cells, Federal University of Pernambuco, 50670-901 Recife-PE, Brazil \\ ${ }^{2}$ Laboratory of Evaluation of Psychobioactive Drugs and their Toxicology, Federal University of Pernambuco, \\ 50670-901 Recife-PE, Brazil \\ ${ }^{3}$ Laboratory of Bioassays for Research and Development of Drugs, Federal University of Pernambuco, \\ 50670-901 Recife-PE, Brazil \\ ${ }^{4}$ Laboratory of Immunology of Parasitic Diseases and Experimental Schistosomiasis, Lika, \\ University of Pernambuco, 50670-901 Recife-PE, Brazil.
}

\begin{abstract}
RESUMO: Cissus sicyoides pertence à família das Vitaceae. É conhecido popularmente como “insulina, cipó-puca, bejuco caro, puci, anil trepador". Esta planta apresenta efeito vasoconstritor eatividade antibacteriana. No Brasil, C. sicyoides foi avaliado pelas suas propriedades anticonvulsivante e anti-diabética. Estudos fitoquímicos identificaram e isolaram a partir de suas partes aéreas o sitoesterol e o resveratrol compostos que são apontados por apresentar atividade antitumoral. O objetivo deste estudo foi investigar as atividades citotóxica e antitumoral do extrato hidroalcoólico Cissus sicyoides bem como a sua capacidade de recrutar leucócitos para os tecidos lesados. Cissus sicyoides não demonstrou atividade citotóxica, mas apresentou uma inibição do crescimento tumoral frente aos tumores testados. O extrato teve um forte efeito quimiotático $24 \mathrm{~h}$ após o tratamento. O extrato hidroalcoólico de Cissus sicyoides apresentou atividade antitumoral, relacionada ao recrutamento de linfócitos $\mathrm{T}$ para o local da lesão sugerindo que esta atividade esteve relacionada à ativação da linhagem linfóide.
\end{abstract}

Unitermos: Cissus sicyoides, atividade antitumoral, migração de leucócitos, ativação da linhagem linfóide.

\begin{abstract}
Cissus sicyoides L. belongs to the Vitaceae family. It is popularly known as "insulina, cipo-pucá, bejuco caro, puci, anil trepador". A vasoconstrictor effect and an antibacterial activity have also been allocated to it. In Brazil, C. sicyoides was evaluated for its anticonvulsant and anti-diabetic properties. Phytochemistry studies identified and isolated sitosterol and resveratrol compounds from its aerial parts which are pointed out as having antitumor activities. The goal of this study was to investigate the cytotoxic and antitumor activities of Cissus sicyoides hydroalcoholic extract as well as its ability to repair leukocytes cells to injured tissue. Cissus sicyoides did not demonstrate cytotoxic activity but showed an inhibition of tumor growth in face of the tumors tested. The extract had a strong chemotactic effect on the $24 \mathrm{~h}$ period after treatment. The hydroalcoholic extract of Cissus sicyoides presented antitumor activity which was prompted by $\mathrm{T}$ lymphocytes recruitment to the local lesion and it suggests a new pathway to antitumor activity by activation of lymphoid lineage.
\end{abstract}

Keywords: Cissus sicyoides, antitumor activity, leukocyte migration, activation of lymphoid lineage.

\section{INTRODUCTION}

Cissus sicyoides L. pertaining to the Vitaceae family is made up of about one hundred sixty five genus and one thousand three hundred seventy species, which are distributed throughout the tropics, mainly in Brazil and the Caribbean. It is popularly known as "insulina, cipopucá, bejuco de porra, bejuco caro, puci, anil trepador" and its origins from the Dominican Republic (Beltrame et al., 2001). It has also demonstrated a vasoconstrictor effect on guinea-pig aorta rings (Pepato et al., 2003) and an antibacterial activity (Garcia et al., 1999). In Brazil, $C$. 
sicyoides was evaluated for its anticonvulsant property, where it is used against epilepsy and cytotoxic activity (Elisabetsky et al., 1995a, b, 1999). Used as an infusion of tea, the treatment induced an increase in the amount of chromosomal damage in bone marrow cells without altering the cell division cycle. (Saénz et al., 2000). The central antinociceptive effect of $C$. sicyoides on mice, and the action of dry leaves extract in pregnant rats and offspring, also showed postal development. (Almeida et al., 2006a, b, 2007). Phytochemistry studies identified and isolated from the aerial parts of $C$. sicyoides a new coumarin glycoside 5,6,7,8-tetrahydroxycoumarin 5ß-xylopyranoside, which was obtained together with known coumarin sabandin: two flavonoids kaempferol 3-rhamnoside and quercetin 3-rhamnoside and two steroids, among them sitosterol, which is pointed out as inducing apoptosis, together with TNF- $\alpha$ and antitumor activity (Park et al., 2007; Beltrame et al., 2002). Leaves of the genus Cissus contain sterols, quinones and phenolic compounds. Anthocyanins, saponins and flavonoids are also found in the plant's leaves and fruit (Beltrame et al., 2002).. Phytochemistry studies demonstrated that $C$. sicyoides has hydroxystilbene resveratrol in its leaves, another compound responsible for antitumor activity. Resveratrol has pleiotropic effects, altering many different signalling pathways (nuclear factornkB, Rb-E2F, p53, phosphatidylinositol 3-kinase/Akt, and mitosis-activated protein kinase pathways), leading to suppression of tumours cell proliferation, adhesion, invasion and metastasis, reduced signs of inflammation and angiogenesis, and induction of apoptosis and differentiation (Bharat et al., 2004). However, there are no references on antitumor activity of Cissus sicyoides. The inflammatory process consists of a sequence of events that affect vascularity (Vasodilatation increased permeability and expression of adhesion molecules) (Bhoola et al., 1992). The leukocytes dynamics on the blood, which are attracted to the focus inflammatory tissue, are important because these cells travel to the tissues from the peripheral blood and carry out a protective functions such as phagocytes by neutrophils and monocytes, release of cytokines by Thelper lymphocytes $(\mathrm{CD} 4+)$ and cytotoxicity by $\mathrm{T}$ lymphocyte cytotoxic (CD8+) (Baumann \& Gauldie, 1994). The goal of this study was to investigate the cytotoxic and antitumor activities of Cissus sicyoides hydroalcoholic extract as well as studying their ability to repair leukocytes cells to the injured tissue.

\section{MATERIAL AND METHODS}

\section{Botanic materials and extract preparation}

Aerial parts of plant material Cissus sicyoides L., Vitaceae, were collected in the Várzia District at Rua Maria Jaboatão $\mathrm{n}^{\circ} 115$, Recife, Brazil during the period of September to March, during the harvest time when the plants produce fruits. The plant was identified by Marlene
Carvalho de Alencar, Curator of the Geraldo Mariz Herbarium-UFPE. The collected species was deposited in the Herbarium under the register 50.541. The leaves were washed and dried in the laboratory at room temperature, then dried in an oven for fifteen days at $\pm 45^{\circ} \mathrm{C}$, after that they were triturated manually. Ethyl alcohol and water was added at a proportion of 70:30 (v/v). The leaves, water and alcohol mixture was then rested for $48 \mathrm{~h}$, followed by mechanical agitation also for $48 \mathrm{~h}$, then submitted to roteevaporation. The extract was dissolved in a physiologic serum solution (Almeida, 2002).

\section{Animals used in the pharmacological tests}

For the tests, Swiss albino female mice (Mus musculus) were used, weighing between 30-35 g, with an average age of two months. The animals were monitored according to the norms of the National Institute of Health Guide for Care and Use of Laboratory Animals. The experiments were conducted according to the National Cancer Institute protocol (Geran et al., 1972) and approved by the UFPE-Animal Experimentation Ethic Committee (Protocol no 018301/2007-96).

\section{Neoplasic cells used in the tests}

The citotoxity tests were conducted using three lines of cells: NCI-H292 cells (mucoepidermoid lung carcinomacells),HEp-2cells(larynx carcinomaepidermoid) and $\mathrm{KB}$ cells (mouth Carcinoma epidermoid).

\section{Cytotoxic activity}

The cells (HEp-2, KB and NCI-H292) were maintained in DMEM-Minimum Essential Medium Eagle modified Dulbecco's (Sigma), (Eagle, 1971) supplement with $10 \%$ fetal bovine serum (Gibco), 1\% solution of antibiotic (penicillin $1000 \mathrm{UI} / \mathrm{mL}+$ streptomycin 250 $\mathrm{mg} / \mathrm{mL}$ ) and $1 \%$ de L-glutamin $200 \mathrm{mM}$. For cytotoxity determination a cellular suspension of $10^{5}$ cells $/ \mathrm{mL}$, was prepared in DMEM. The suspension was distributed in culture plaques with 96 wells $(225 \mu \mathrm{L}$ in each well). The plaques were incubated at $37{ }^{\circ} \mathrm{C}$ in a $\mathrm{CO}_{2}(\mathrm{COLE}$ PARMER) incubator. After $24 \mathrm{~h}(25 \mu \mathrm{L} /$ well $)$ was added to the tested substances and the plaques were incubated at $37^{\circ} \mathrm{C}$ (Costa \& Nascimento, 2003). Evaluation of cytotoxic activity was carried out by MTT colorimetric essay [3-(4,5Dimethylthiazol-2-yl)-2,5-diphenyltetrazolium bromide, a tetrazole] in a PBS concentration of $5 \mathrm{mg} / \mathrm{mL}$. The plaques were placed in an oven at $37{ }^{\circ} \mathrm{C}$ for $2 \mathrm{~h}$. At the end of this time, the culture medium along with the excess MTT material were aspirated, mixed with $100 \mu \mathrm{L}$ of DMSO and added to each well to dissolve the Formazan crystals (Alley et al., 1988; Machon et al., 1981). An optic reading was carried out in an automatic plaque reader BIOPLUS (BIO 2000) at $540 \mathrm{~mm}$. 


\section{Antitumor Activity}

The animals received $0.2 \mathrm{~mL}$ of a suspension $(5 \times$ $10^{6}$ cells/animal) prepared from a cellular suspension of 25 $\times 10^{6}$ cellules $/ \mathrm{mL}$ (animal donator). The treatment of $0.2 \mathrm{~mL}$ leaf suspension was initiated $24 \mathrm{~h}$ later in the right axillary region of the healthy animals. The donator animals were sacrificed with xilasin. These animals were divided into groups, the first being the control group, receiving a saline solution $(\mathrm{NaCl} 0.9 \%)$. The second group was submitted to a treatment with $C$. sicyoides hidroalcoholic extract to evaluate the antitumor activity. The extract dosages were based on DL50 as referred by (Almeida et al., 2006b). The animals received a dose of $300 \mathrm{mg} / \mathrm{kg}$ and $600 \mathrm{mg} / \mathrm{kg}$ of body weight via peritoneal injection. At the end of the treatment, the animals were sacrificed with a fatal dose of xilasin. The tumors were removed and weighed to evaluate the tumor inhibition. The same procedure was adopted for the control group of animals. The tumor inhibition was calculated according to (Machon et al., 1981). The average corporal weight of the animals in the control and treated groups was also observed.

\section{Migration of cells verification (peripheral blood)}

The animals were anesthetized with a solution of $100 \mu \mathrm{L}(2: 8)$ containing xylazine/ketamine to be able to count total leukocytes and lymphocytes from the blood. Samples were collected by cardiac puncture to the amount of $0.5 \mathrm{~mL}$ and preserved in $0.001 \mathrm{~mL}$ of EDTA $10 \%$ and subsequently subjected to automated counting (3200 BC) of the blood slides which were prepared, in duplicate, immediately after collection. Slides were stained with hematoxylin and the eosin analysis cell was counted under optic microscope $(1000 \mathrm{x})$. The analysis was performed 2, 6 and $24 \mathrm{~h}$ after treatment.

\section{Migration of cells verification (peritoneal cavity)}

The peritoneal cavity received, $4 \mathrm{~mL}$ of sterile solution PBS $10 \mathrm{mM}$ EDTA. Around $3 \mathrm{~mL}$ of peritonitis were aspirated and submitted to the refrigerated centrifuge for $7 \mathrm{~min}$ at $1500 \mathrm{rpm}$. The supernatant was collected and the pellet diluted in $100 \mu \mathrm{L}$ and $500 \mu \mathrm{L}$ of $\mathrm{PBS}+0.1 \%$ of BSA. The slides were analyzed as described above.

\section{Statistical analyses}

Cytotoxic and antitumor data were analyzed by statistical analysis software GraphPad Instat 3.0. The results were submitted to the paired $\mathrm{T}$ test and analysis of variance (ANOVA) followed by the test of multiple comparisons of Tukey-Kramer. The migration activity was analyzed by (Wilcoxon) and Mann-Whitney tests.

\section{RESULTS}

\section{Cytotoxic activity}

The Cissus sicyoides L., Vitaceae, hidroalcoholic leave extract did not demonstrate cytotoxic activity at tested concentrations, $(\mathrm{CI} 50>50 \mu \mathrm{g} / \mathrm{mL})$.

\section{Antitumor activity}

The hydroalcoholic extract from the leaves of C. sicyoides showed an inhibition of tumor activity in sarcoma- 180 of 48.7 and $62 \%$ to the doses of 300 and $600 \mathrm{mg} / \mathrm{kg}$ respectively, when compared to tumors with the control group. (Table 1) When Ehrlich Carcinoma was considered, the inhibition was 69 and $84.4 \%$ to the doses of 300 and $600 \mathrm{mg} / \mathrm{kg}$ weight respectively in comparison with the control group (Table 2). Considering the change in weight of animals, significant differences were seen in the weight of animals belonging to the Ehrlich carcinoma group in the dose of $300 \mathrm{mg} / \mathrm{kg}$. The results were considered significant when they showed tumor inhibition growth above $40 \%$ according to the protocol of Geran $\mathrm{e}$ colaboradores (1972).

\section{Leukocytes migration evaluation}

Regarding the number of leukocytes in peripheral blood, the hydroalcoholic extract of $C$. sicyoides did not lead to change in normal values of these cells in any of the times studied, as compared to the control group animals. In the case of leukocytes in the peritoneal cavity, the extract had a strong chemotactic effect on the $24 \mathrm{~h}$ period, since there was a greater quantity of these cells in the group that received the extract in relation to that which received saline (Table 3). Considering the number of lymphocytes, it was observed that within $24 \mathrm{~h}$ the extract led to lymphocytopenia in the peripheral blood (Table 3). Otherwise, the analysis of the peritoneal cavity showed that there was a significant amount of lymphocytes due to the presence of the extract within $24 \mathrm{~h}$, compared to the control group. These results suggest that the lymphocytopenia observed reflected the migration of these cells to peripheral blood to the peritoneal cavity (Table 3).

Table 1. Antitumor activity of Cissus sicyoides L., Vitaceae hydroalcoholic extract (Sarcoma 180).

\begin{tabular}{cccc}
\hline Groups & $\begin{array}{c}\text { Animal } \\
\text { weight } \mathrm{g} \pm \mathrm{SD}\end{array}$ & $\begin{array}{c}\text { Tumor } \\
\text { weight } \mathrm{g} \pm \mathrm{SD}\end{array}$ & $\begin{array}{c}\text { Inhibition } \\
(\%)\end{array}$ \\
\hline Control $(\mathrm{NaCl} 0.9 \%)$ & $33.1 \pm 0.44$ & $1.97 \pm 0.21$ & 0 \\
Treated $(300 \mathrm{mg} / \mathrm{kg})$ & $33.8 \pm 0.32$ & $1.01 \pm 0.08$ & $48.7^{* *}$ \\
Treated $(600 \mathrm{mg} / \mathrm{kg})$ & $35.9+0.21$ & $0.75+0.05$ & $62.0 * *$ \\
\hline
\end{tabular}

Used doses $300 \mathrm{mg} / \mathrm{kg}$ and $600 \mathrm{mg} / \mathrm{kg}$ by peritoneal injection $\mathrm{SD}=$ standard deviations

$* * p<0.01$ 


\section{DISCUSSION}

Among the medical properties attributed to plants and a gamut of varieties encountered in tropical countries, among them Brazil, there is innumerable research with the objective of identifying efficient activities against cancer, from which several studies are being made to find active substances against cancer (Costa \& Nascimento, 2003). There are various indications of Cissus sicyoides L., Vitaceae, being used as popular medicine; many confirmed
Table 2. Antitumor activity of Cissus sicyoides L., Vitaceae hydroalcoholic extract (Ehrlich Carcinoma).

\begin{tabular}{cccc}
\hline Groups & $\begin{array}{c}\text { Animal } \\
\text { weight } \mathrm{g} \pm \mathrm{SD}\end{array}$ & $\begin{array}{c}\text { Tumor } \\
\text { weight } \mathrm{g} \pm \mathrm{SD}\end{array}$ & $\begin{array}{c}\text { Inhibition } \\
(\%)\end{array}$ \\
\hline Control $(\mathrm{NaCl} 0.9 \%)$ & $36.5+0.96$ & $2.09+0.24$ & 0 \\
Treated $(300 \mathrm{mg} / \mathrm{kg})$ & $32.6+0.71^{*}$ & $0.65+0.07 * *$ & $69.0^{* *}$ \\
Treated $(600 \mathrm{mg} / \mathrm{kg})$ & $35.0+0.79$ & $0.32+0.05^{* *}$ & $84.4^{* *}$ \\
\hline
\end{tabular}

Dose used $=300 \mathrm{mg} / \mathrm{kg}$ and $600 \mathrm{mg} / \mathrm{kg}$ peritoneal injection. $\mathrm{SD}=$ standard deviations

$* p<0.05 * * p<0.01$

Table 3. Leukocyte migration to peritoneal cavity and peripheral blood.

\begin{tabular}{lcccc}
\hline \multirow{2}{*}{ Groups } & \multicolumn{2}{c}{ Mean of cells+SD (cavity) } & \multicolumn{2}{c}{ Mean of cells+SD (blood) } \\
& Leucocytes & Lymphocytes & Leucocytes & Lymphocytes \\
\hline Control $(2 \mathrm{~h})$ & $7.5+0.82$ & $7.4+0.81$ & $4.5+0.28$ & $4.0+0.36$ \\
Treated $(2 \mathrm{~h})$ & $1.4+0.43 *$ & $6.6+0.64$ & $3.8+0.40$ & $6.93+0.54$ \\
Control $(6 \mathrm{~h})$ & $14.1+1.38$ & $7.2+0.59$ & $4.9+0.05$ & $4.9+0.17$ \\
Treated $(6 \mathrm{~h})$ & $15.4+1.5$ & $4.0+0.84$ & $4.9+0.63$ & $4.5+0.66$ \\
Control $(24 \mathrm{~h})$ & $4.9+0.03$ & $2.5+0.4$ & $7.2+0.75$ & $6.7+0.49$ \\
Treated $(24 \mathrm{~h})$ & $* * 25.3+1.45$ & $* * 19.4+0.5$ & $4.3+0.87$ & $4.3+0.87$ \\
\hline
\end{tabular}

Dose used $=300 \mathrm{mg} / \mathrm{kg}$ of CS/peritoneal injection.

Control group $=\mathrm{NaCl} 0.9 \%$

$\mathrm{SD}=$ Standard deviation

Referential values leucocytes (4-12).

Referential values lymphocytes (3-9).

$* p<0.05$

$* * p<0.01$

by well known methodologies recognized in international literature, this plant is used as an anticarcinogenic in the treatment of gall bladder cancer (Quílez, 1996) and it was verified in this study that the hidroalcoholic extract produced from $C$. sicyoides leaves did not demonstrate cytotoxic activity at the concentrations tested, (CI50 $>50$ $\mu \mathrm{g} / \mathrm{mL}$ ) and for the plant extract to be considered active the CI50 should be less than, or equal to, $30 \mu \mathrm{g} / \mathrm{mL}$ for plant extracts (Geran et al., 1972). Meanwhile, when the antitumor activity was carried out in vivo it was observed that the hidroalcoholic extract of the C. sicyoides leaves presented an inhibition to Sarcoma- 180 of $48.7 \%$ to the 300 $\mathrm{mg} / \mathrm{kg}$ and $62 \%$ to the $600 \mathrm{mg} / \mathrm{kg}$ treatment. In relation to the Ehrlich Carcinoma, the inhibition was $69 \%$ in the 300 $\mathrm{mg} / \mathrm{kg}$ treatment and $84.4 \%$ in the $600 \mathrm{mg} / \mathrm{kg}$ treatment suggesting that the antitumor activity could be related to the metabolism of active compounds in secondary metabolites. This interaction is impossible to be visualized in vitro, seeing that the culture in vitro metabolic reactions, as in live organisms, does not exist. Tested substances and a gambit of reactions with hormones, enzymes and liver metabolism are capable of influencing the functions of tested substances in organism. This antitumor activity can be related to the presence of sitosterol which is pointed out as inducing apoptosis together with TNF- $\alpha$ and antitumor activity (Park et al., 2007) and hydroxystilbene resveratrol, another compound responsible for antitumor activity.
Resveratrol has pleiotropic effects, altering many different signalling pathways i.e., nuclear factor-n $\kappa \mathrm{B}, \mathrm{Rb}-\mathrm{E} 2 \mathrm{~F}, \mathrm{p} 53$, phosphatidylinositol 3-kinase/Akt, and mitogen-activated protein kinase pathways, leading to suppression of tumor cell proliferation, adhesion, invasion and metastasis, reduced signs of inflammation and angiogenesis, and induction of apoptosis and differentiation (Bharat et al., 2004). In relation to cells migration, no changes in the number of total leukocytes between the treated and control groups were verified, but the results demonstrated that the extract had a strong chemotactic effect on the $24 \mathrm{~h}$ study. In relation to the lymphocytes number (important against tumor development) the results showed that the extract led to a lymphocytopenia on the peripheral blood. Otherwise, the analysis of peritoneal cavity showed that there was a significant amount of lymphocytes due to the presence of the extract within $24 \mathrm{~h}$, compared to the control group .These results suggest that lymphocytopenia observed reflects the migration of these cells to peripheral blood until the peritoneal cavity. Moreover, the stimulation of leukocyte influx becomes important in protecting against tumors. In this study, we found that the hydroalcoholic extract from the leaves of $C$. sicyoides was able to attract lymphocytes to the site of its application. Knowing that in the line lymphoid cells are cells that are specialized in the death of tumors, such as CD8+ lymphocytes cytotoxic cells and release of cytokines by $\mathrm{T}$ helper lymphocytes (CD4+) (Baumann \& Gauldie, 1994; Ferreira et al., 2001). These results prompt the potential of hydroalcoholic extract from the leaves of $C$. sicyoides by lymphoid cell stimulation/ attraction pathway. In conclusion, the hidroalchoolic extract of C. sicyoides presented antitumor activity which was prompt by $\mathrm{T}$ lymphocytes recruitment to the injured 
tissue and suggests a new pathway to antitumor activity by activation of lymphoid lineage.

\section{ACKNOWLEDGEMENTS}

The authors are grateful for the financial assistance given by CAPES-Brasil (Coordenação de Aperfeiçoamento de Pessoal de Nível Superior).

\section{REFERENCES}

Alley MC, Scudiere DA, Monks A, Hursey ML, Czerwinski MJ, Fine DL, Abbott BJ, Mayo JG, Shoemaker RH, Boyd MR 1988. Feasibility of drug screening with panels of human tumor cell lines using a microculture tetrazolium assay. Cancer Res 48: 589-601.

Almeida ER 2002. Estudo da atividade antinociceptiva central do extrato hidroalcoólico das sementes de Dioclea grandiflora Mart ex. Benth (Fabaceae) e dois de seus constituintes quimicos: Dioclenol e Dioflorina. João Pessoa, 78p. Tese de Doutorado, Programa de Pós Graduação em Ciências Farmacêuticas, Universidade Federal da Paraíba.

Almeida ER, Oliveira JRG, Lucena FRS, Soares RPF 2006a. The action of extract of the dry leaves of Cissus sicyoides in pregnant rats. Acta Farm Bonaer 25: 421-424.

AlmeidaER, Soares RPF, Lucena FRS, Oliveira JRG, Albuquerque JFC, Bosco GBL 2006b. Central antinociceptive effects of Cissus sicyoides on mice. Pharm Biol 44: 304-308.

Almeida ER, Oliveira JRG, Lucena FRS, Soares RPF, Cavalcanti JB, Couto GBL 2007. Embriofetotoxic effect and offspring postnatal development exposed to hydroalcoholic fraction extract of Cissus sicyoides during Wistar rats pregnancy. J Med Plant Res 1: 109-112.

Baumann H, Gauldie J 1994. The acute phase response. Immunol Today 15: 74-80.

Beltrame FL, Sartoretto JL, Bazotte RBR 2001. Estudo fitoquímico e avaliação do potencial antidiabético do Cissus sicyoides L. (Vitaceae). Quim Nova 24: 783-785.

Beltrame FL, Ferreira A, Cortez DAG 2002. Coumarin Glycoside from Cissus Sicyoides. Nat Prod Res 16: 213-216.

Bharat B, Aggarwal L, Bhardwaj LA, Rishi S, Navindra P, Shishodia SS, Takada Y 2004. Role of Resveratrol in Prevention and Therapy of Cancer: Preclinical and Clinical Studies. Anticancer Res 24: 3-60.

Bhoola KD, Figueroa CD, Worthy K 1992. Bioregulation of kinins; kallikreins and kinases. Pharmacol Rev 44: 4-80.

Costa MCCD, Nascimento SC 2003. Atividade citotóxica de Plectranthus barbatus Andr. (Lamiaceae). Acta Farm Bonaer 22: 155-158.

Elisabetsky E, Marschner J, Souza DO 1995a. Effects of Linalool on glutamatergic system in the rat cerebral cortex. Neurochem Res 20: 461-465.

Elisabetsky E, Coelho de Souza GP, dos Santos MAC, Siquieira IR, Amador TA, Nunes DS 1995b. Sedative properties of linalool. Fitoterapia 66: 407-414.
Elisabetsky E, Brum LF, Souza DO 1999. Anticonvulsant properties of linalool in glutamate-related seizure models. Phytomedicine 6: 107-113.

Eagle HB 1971. Combinations for mammalian cell culture. Science 8: 500-503.

Ferreira J, Campos MM, Pesquero JB, Araujo RC, Bader M, Calixto JB 2001. Evidence for the participation of kinins inFreund's adjuvant-induced inflammatory and nociceptiveresponses in kinin B1 and B2 receptor knockout mice. Neuropharmacology 41: 1006-1012.

Garcia MD, Saenz MT, Puerta R, Quilez A, Fernandez MA 1999. Antibacterial activity of Agave intermixta and Cissus sicyoides. Fitoterapia 70: 71-73.

Geran RI, Greenberg NH, Macdolnald MM, Schumacher AM, Abbott BJ 1972. Protocols for screening chemical agents and natural products against animal tumors and other biological systems. Cancer Chemother Rep 3: 1-103.

Machon Z, Kuczynski L, Gieldanowski J, Wieczorek Z, Zimecki M, Blaszczyk B, Mordaski M, Wieczorec J, FiszerMaliszewska L 1981. Chemical and biological properties of 2-pyridyl-benzil-carbinol. Arch Immunol Ther Exp 29: 217-223.

Park C, Moon D, Rhu CH, Choi BT, Lee WH, Kim GY, Choi YH 2007. $\beta$-Sitosterol Induces Anti-proliferation and Apoptosis in Human Leukemic U937 Cells through Activation of Caspase-3 and Induction of Bax/Bcl-2 Ratio. Biol Pharm Bull 30: 1317-1323.

Pepato MT, Baviera AM, Vendramini RC, Perez MP, Kettelhutid C, Brunetti IL 2003. Cissus sicyoides (Princess wine) in the long terme treatment of streptozotocin-diabetic rats. Biotechnol Appl Bioc 37: 15-20.

Quílez A 1996. Investigacion fitoquimica y bioensayos de substancias obtenidas de plantas empleadas em diferentes tipos de câncer em Republica Dominicana. Anais da IX jornada farmacêuticas de la Universidad Nacional Pedro Henríquez Ureña. Santo Domingo, República Dominicana.

Sáenz MT, Garcia MD, Quilez A, Ahuamada MC 2000. Cytotoxic activity of Agave intermixta L. (Agavaceae) and Cissus sicyoides L. (Vitaceae). Phythoter Res 14: 552-554. 